\title{
FLUORIDE LEVELS IN SALIVA AFTER CHEWING BLACK TEA CANDY (CAMELLIA SINENSIS) IN CHILDREN
}

Lisa Prihastari ${ }^{\star}$ Emha Ananda Poetra**

${ }^{*}$ Departement of Preventive and Public Health Dentistry, Faculty of Dentistry, Universitas Yarsi

**Undergraduate Student, Faculty of Dentistry, Universitas Yarsi

Correspondence: lisa.prihastari@yarsi.ac.id

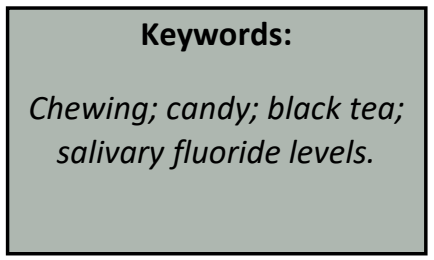

\begin{abstract}
Background: Black tea has been shown to affect reducing dental plaque and increasing fluoride levels in saliva. The practice of consuming black tea in the form of candy for dental health purposes is not familiar yet. A study on the effectiveness of chewing black tea candy added with sorbitol sugar for a month on salivary fluoride levels in children aged 7-8 years can be an innovation in the prevention of dental caries. This study aims to investigate the difference in fluoride levels in saliva before and after chewing black tea candy for one month in children aged 7-8 years.
\end{abstract}

Method: This is a field experimental study with double-blind and randomization. Subjects involved in this study were 44 children divided into control and intervention groups using simple random sampling. Measurement of salivary fluorine levels using the TECAN Infinite M200 Pro ${ }^{\circledast}$ UV - VIS Spectrophotometer for 3 times.

Result: The results of the independent T-test showed that there were significant differences in the fluorine content in the intervention group using black tea candy on 26 November 2019, 29 November 2019, and 16 December 2019 ( $p<0.05)$.

Conclusion: Chewing black tea candy is effective in increasing the amount of fluoride in saliva. Thus, it can be an alternative to anti-cariogenic agents.

\section{INTRODUCTION}

Teeth are one of the components of the chewing system in the human body. The main problem that often occurs in children's teeth is caries. According to the Basic Health Research (Riset Kesehatan Dasar, abbreviated as Riskesdas) data in 2018, the prevalence of active caries in Indonesia is $88.8 \%$ with a prevalence in children aged $5-9$ years old of $92.6 \% .^{1}$ Furthermore, Indonesia's DMF-T index in 2013 was 4.6 with each value of $D=1.6 ; M=2.9 ; F=0.08$; indicating that the Indonesian population decayed 460 teeth per 100 people. ${ }^{2}$ Dental caries is a disease that affects many children. Thus, the childhood period needs special attention, especially those aged 6-9 years old. At the age of 6 years old, permanent molars 
that are more prone to caries have started to grow. Efforts to control plaque and dental caries can be done in two ways, namely by mechanical and chemical processes. The mechanical approach is to use a toothbrush and toothpaste, while the chemical method is to use anti-cariogenic chemicals. In Indonesia, the use of herbal plants as an anticariogenic material has been widely used. Yet, those herbal plants are very rare to be tested at the in vivo level in humans. Various studies have proven that black tea is one of the herbal plants that is safe and effective tested on animals and humans to reduce plaque, and is able to have anti-bacterial properties while increasing fluoride levels. ${ }^{3-9}$ In Indonesia, the majority of people like consuming tea, especially black tea. Tea is also one of the popular beverage products in various countries, especially in Asian countries. Black tea has higher levels of fluoride compared to green tea. High levels of fluoride can form dental hydroxyapatite crystals that are more acid-resistant to make it more difficult to demineralize. ${ }^{10-12}$

The use of tea in the form of candy as an anticariogenic ingredient has not been widely researched and applied in Indonesia. Even if it is served in the form of candy, it is possible that black tea might be more acceptable and preferred by children. Black tea candy as an anti-cariogenic ingredient should not be given sucrose sweetener which can easily be fermented by Streptococcus mutans bacteria. Therefore, sorbitol sugar is needed as a substitute material. Sorbitol is one of the natural sugar alcohols with the chemical formula of $\mathrm{C}_{6} \mathrm{H}_{14} \mathrm{O}_{6}$, commonly in the form of white crystalline powder odorless, anti-cariogenic, and relatively sweeter than sucrose sugar. ${ }^{13}$ This study aims to determine the effectiveness of black tea candy in increasing salivary fluoride levels after almost a month of routine consumption.

\section{METHODS}

This study was carried out in November January 2019 in two different schools in South Jakarta and Central Jakarta, Indonesia which were selected by purposive sampling. Laboratory testing was carried out at the herbal laboratory of Universitas YARSI using the TECAN Infinite M200 Pro $^{\circledR}$ UV-VIS Spectrophotometer.

This study is a field experimental study type with a double-blind randomized clinical trial study design, in which the researcher and the subjects did not know the names and actions given to the control group or the case group. The research design was in the form of a pretest-posttest control group design where an ethics feasibility test was conducted in advance at the ethics commission of Universitas YARSI (No: 227/KEP-UY/BIA/XI/2019)

The subjects involved in this study were elementary school children aged 7-8 years in a simple random sampling with an initial number of 60 children. However, since there was a dropout along the way, there were only 44 subjects who were divided into 24 children in the control group and 20 children as the intervention or treatment group. The inclusion criteria for subjects were students in first and second grade aged 7-8 years, had no systemic disease, had never received a routine tea candy consumption program, and did not routinely use mouthwash. The exclusion criteria of the study were students' which parents were unwilling to have their children involved in the study, subjects who were not cooperative during the implementation, students who were receiving fluoride application treatment both systemic and topical, students who had a history of taking antibiotics for three months, and poor oral hygiene. Each subject was given a consent form and research explanation before participating in this study. 
Black tea is made in the form of hard candy with ingredients, namely black tea extract, powdered sugar sorbitol, isomalt, water, dyes, and flavorings. The ingredients were then mixed, dissolved, and heated to a boil, and then poured into a mold. After the candy had fully hardened, it was removed from the mold and wrapped in plastic packaging. The black tea candy was then ready to be consumed.

Before the study was conducted, the researchers examined the subjects' dental and oral hygiene using the OHIS index. The researchers also performed a scaling action for simple cases to ensure that the research subjects' conditions were different at the same level. The study was conducted for 3 weeks and 3 times examinations were carried out at baseline, 7 days after treatment, and 23 days after treatment. The subjects' saliva was collected in a $5 \mathrm{ml}$ test tube before being instructed to chew black tea candy and placebo candy (containing sorbitol). After finishing chewing the candy, the subject was asked again to spit to collect saliva into the test tube. The chewing activity of black tea candy was carried out every day while at school coordinated by the researchers. Before measuring the fluorine level of saliva in the test tube sample, the absorbance of the solution was measured by calculating the maximum wavelength produced by the sodium fluoride ( $\mathrm{NaF}$ ) solution and SPADNS reagent, namely $\lambda=510 \mathrm{~nm}$. This method had a disadvantage, for the concentration of the solution was too thick, when irradiating the results of the maximum wavelength cannot be determined with certainty which accordingly affects the absorbance value.

\section{RESULTS}

The frequency distribution of research subjects based on the treatment group and gender is presented in table 1 which shows that in the black tea candy group there were 20 children $(50 \%)$ and the remaining 24 children (50\%) in the placebo candy group. Further, the table also describes the proportion of the gender variable where the number of the girls is more (59.1\%) compared to boys $(40.9 \%)$.

Table 2 presents the paired t-test results of the black tea candy group showed that there was a significant difference before and after chewing black tea candy. There was a tendency to increase in fluoride levels in saliva during the first measurement (baseline; $p$-value $=0.0001$ ), the second measurement (after 7 days; $p$-value $=$ 0.0001 ), and the third measurement (after 23 days; $p$-value $=0.004)$. In the placebo group, the test results also showed a significant difference. However, the tendency was to decrease fluoride levels before and after chewing candy containing sorbitol alone.

The difference in fluoride levels between the control and treatment groups can be seen from a comparison of the difference in fluoride levels after chewing and before chewing was carried out in the first, second, and third measurements. The results are presented in Table 3 above. The difference in mean fluoride levels between the two groups was significant in all measurements and revealed that the difference was favorable for the black tea group. It indicates that fluoride levels had increased, while it was negative in the placebo group. 
Table 1. Frequency Distribution of Research Subjects

\begin{tabular}{cccccccc}
\hline & \multicolumn{4}{c}{ Group } & \multicolumn{2}{c}{ Total } \\
\cline { 2 - 5 } Variable & \multicolumn{2}{c}{$\begin{array}{c}\text { Black Tea } \\
\text { Candy }\end{array}$} & \multicolumn{2}{c}{$\begin{array}{c}\text { Placebo } \\
\text { Candy }\end{array}$} & & \\
\cline { 2 - 6 } & $\mathbf{N}$ & $\%$ & $\mathbf{N}$ & $\%$ & $\mathbf{N}$ & $\%$ \\
\hline $\begin{array}{c}\text { Number of subjects } \\
\text { Gender: }\end{array}$ & 20 & 50 & 24 & 50 & 44 & 100 \\
Male & 9 & 45 & 9 & 37.5 & 18 & 40.9 \\
Female & 11 & 55 & 15 & 62.5 & 26 & 59.1 \\
\hline
\end{tabular}

Table 2. Results of the Paired T-Test for fluoride levels before and after chewing candy

\begin{tabular}{cccc}
\hline & Kadar & \multicolumn{2}{c}{ Group } \\
\cline { 3 - 4 } & $\begin{array}{c}\text { Fluoride } \\
\text { Saliva }\end{array}$ & Black Tea Candy & Placebo Candy \\
\cline { 3 - 4 } & & Mean \pm SD & Mean \pm SD \\
\hline $\begin{array}{c}\text { First } \\
\text { examination }\end{array}$ & Before & $0.84 \pm 0.36$ & $1.29 \pm 0.24$ \\
& After & $1.26 \pm 0.29$ & $1.09 \pm 0.37$ \\
\hline & p-value & $0.0001^{*}$ & 0.034 \\
\hline Second & Before 2 & $0.87 \pm 0.42$ & $1.27 \pm 0.36$ \\
examination & After 2 & $1.25 \pm 0.36$ & $1.08 \pm 0.35$ \\
\hline \multirow{2}{*}{ Third } & p-value & $0.0001^{*}$ & 0.0001 \\
\hline examination & Before 3 & $0.99 \pm 0.42$ & $1.17 \pm 0.37$ \\
& After 3 & $1.37 \pm 0.35$ & $1.00 \pm 0.34$ \\
\hline \multirow{2}{*}{} & p-value & $0.004^{*}$ & 0.084
\end{tabular}

*Significance of relationship at $p<0.05$

Table 3. Results of the Independent T-Test were the difference in fluoride levels between the two groups

\begin{tabular}{|c|c|c|c|}
\hline \multirow{3}{*}{$\begin{array}{c}\text { Saliva } \\
\text { Fluoride } \\
\text { Levels }\end{array}$} & \multicolumn{2}{|c|}{ Group } & \multirow{3}{*}{ p-value } \\
\hline & Black Tea Candy & Placebo Candy & \\
\hline & Mean $\pm S D$ & Mean $\pm S D$ & \\
\hline$\Delta 1$ & $0.42 \pm 0.29$ & $(-0.19) \pm 0.41$ & $0.0001^{*}$ \\
\hline$\Delta 2$ & $0.22 \pm 0.35$ & $(-0.19) \pm 0.13$ & $0.0001^{*}$ \\
\hline$\Delta 3$ & $0.38 \pm 0.53$ & $(-0.16) \pm 0.53$ & $0.001^{*}$ \\
\hline \multicolumn{4}{|c|}{$\begin{array}{l}\text { Significance of relationship at } p<0.05 \\
\text { Description: } \\
\Delta 1 \text { : salivary fluoride levels after chewing candy - before chewing candy at baseline } \\
\Delta 2 \text { : salivary fluoride levels after chewing candy - before chewing candy on the second } \\
\text { measurement }\end{array}$} \\
\hline
\end{tabular}




\section{DISCUSSION}

This study has successfully proven that black tea has the ability to increase fluoride levels in saliva even though the preparation has been converted into candy form (see Table 2 and 3). At the first measurement, the fluoride level before chewing black tea was $0.84 \pm 0.36 \mathrm{ppm}$ which was then increased to $1.26 \pm 0.29 \mathrm{ppm}$. At the second and third measurements, the fluoride levels before chewing black tea candy were $0.87 \pm 0.42 \mathrm{ppm}$ to $1.25 \pm 0.36 \mathrm{ppm}$, and $0.99 \pm 0.42 \mathrm{ppm}$ to $1.37 \pm 0.35$ ppm consecutively. In contrast, the placebo group that chewed sorbitol candy actually experienced a decrease in fluoride levels in their saliva at each measurement time. This finding is confirmed by previous studies that black tea consumption can increase the fluoride intake of saliva. ${ }^{14,15}$ Meanwhile, the application of sorbitol sugar would not have a noticeable effect on the rise in fluoride to avoid demineralization. ${ }^{16}$ The concentration of fluoride in black tea is affected by a lot of factors, including the form of species variant, the environment in which it is cultivated, the method of planting or horticulture, the process of harvesting, the mechanical processing, as well as the packaging. How to consume brewed tea might also affect the dissolved fluoride, for example, the temperature of the water used for brewing, the size and shape of the tea used, the length of time for brewing the tea, and many others. ${ }^{15}$

Changes in tea preparations that are usually given in the form of infusion into hard candy were found not to reduce their ability to increase fluoride levels in saliva, this is supporting other studies that state that giving tea mixed with milk does not reduce its fluorine ion content. ${ }^{17,18}$ The provision of tea preparations in the form of candy was not only intended to be more acceptable and preferred by children but also with the thought of preventing the effect of stain formation or stains if given in the form of a mouth rinse continuously due to the tanning content in the tea. ${ }^{19,20}$ However, further testing is needed in this regard.

Increased levels of fluoride in saliva due to the ingestion of tea candy may play a role in the prevention of dental caries in children as it improves remineralization and is more immune to bacterial acids. ${ }^{21,22} \mathrm{~A}$ long-term study of 2 years may reduce children's dental caries by measuring DMFS and DMFT as conducted by Toumba KJ, Curzon ME.23 The use of fluoride content in black tea may also be combined with casein in milk to prevent dental caries, although not many studies support this. ${ }^{24}$

The limitation of this study was that the measurement time was only 3 weeks. Longitudinal studies were needed to see the anti-cariogenic effects of black tea for at least 6 months to 2 years. Moreover, it is also necessary to compare the effects of using black tea with other fluoride preparations such as $\mathrm{NaF}, \mathrm{SnF}, \mathrm{APF}, \mathrm{SDF}$, et cetera, as well as other anti-cariogenic materials such as xylitol to prevent new caries. Furthermore, it is also necessary to measure the risk of fluoride intake due to the regular consumption of this black tea candy in humans, especially children.

The inadequate fluoride supplementation program in Indonesia may be one of the causes of the high caries rate in this country. The use of fluoride toothpaste, which is promoted by the government, has not yielded satisfactory results. Indonesia is one of the best tea-producing countries in the world. Studies that prove that tea plants in Indonesia are capable of being a sufficient source of fluoride to prevent caries can be used as evidence-based solutions to reduce high caries rates, especially in children. 


\section{CONCLUSION}

Hard candy with black tea content has the ability to increase fluoride levels in saliva. Therefore, it can be an alternative to prevent dental caries.

\section{ACKNOWLEDGMENT}

This study was supported by LPPM Universitas YARSI for financial support as a part of internal grants 2019.

\section{REFERENCES}

1. Badan Penelitian dan Pengembangan Kesehatan. Riset Kesehatan Dasar. (RISKESDAS) 2013. Lap Nas 2013. pp.1-306.

2. Badan Penelitian dan Pengembangan Kesehatan. Riset Kesehatan Dasar (RISKESDAS) 2018. Lap Nas 2018..pp.238.

3. Ramadan, A. M., Bakeer, H. A., Mahrous, M. S., \& Hifnawy, T. M. Influence of black tea on Streptococcus mutans and Lactobacillus levels in saliva in a Saudi cohort. 2019. Journal of Taibah University Medical Sciences, 14(2), 179-186.

https://doi.org/10.1016/j.jtumed.2019.02.0083

4. Armidin, R. P., \& Yanti, G. N. Effectiveness of Rinsing Black Tea Compared to Green Tea in Decreasing Streptococcus mutans. 2019. Open access Macedonian journal of medical sciences, $\quad 7(22)$, 3799-3802. https://doi.org/10.3889/oamjms.2019.507

5. Hamdi K, Shoae Hassani A, Ordouzadeh N, Ghaemi A. The effect of black and green-tea extracts on dental-plaque forming Streptococci. J Shahrekord Univ Med Sci. 2008; 10 (3) :1-8

6. Gupta P., Sandesh N. Estimation of fluoride concentration in tea infusions, prepared from different forms of tea, commercially available in Mathura city.2012. J. Int. Soc. Prev. Comm. Dent. 2012;2:64-68. doi: 10.4103/22310762.109371.

7. Subramaniam P., Maheshwar Reddy K., Eswara U. Effect of different types of tea on Streptococcus mutans: an in vitro study. 2012. Indian J Dent Res. 2012;23(1):43.

8. Linke HA, LeGeros RZ. Black tea extract and dental caries formation in hamsters. Int J Food Sci Nutr. 2003 Jan;54(1):89-95. doi: 10.1080/096374803/000062029. PMID: 12701240.

9. Arya V, Taneja L, Srivastava A, Nandlal S. Anticariogenic Activity of Black Tea - An Invivo Study. J Clin Diagn Res. 2016 Mar;10(3):ZC747. doi: 10.7860/JCDR/2016/16276.7489. Epub
2016 Mar 1. PMID: 27135007; PMCID: PMC4843392.

10. Yuwono, Mochammad. Determination of fluoride in black, green and herbal teas by ionselective electrode using a standard-addition method. 2005. Maj Ked Gigi. 38. 10.20473/j.djmkg.v38.i2.p91-95.

11. Esfehani, M., Ghasemzadeh, S., \& Mirzadeh, M. (2019). Comparison of Fluoride Ion Concentration in Black, Green and White Tea. International Journal of Ayurvedic Medicine, 9(4), 263-265. Retrieved from https://ijam.co.in/index.php/ijam/article/view/11 $\underline{10}$

12. Smolik, Beata \& Pelc, Justyna \& Śnioszek, Martyna \& Smolik, Miłosz. (2017). Fluoride Content Of Teas Available On The Polish Market. Fluoride. 50. 292-299.

13. Burt BA. The use of sorbitol- and xylitolsweetened chewing gum in caries control. J Am Dent Assoc. 2006 Feb;137(2):190-6. doi: 10.14219/jada.archive.2006.0144. Erratum in: J Am Dent Assoc. 2006 Apr;137(4):447. PMID: 16521385.

14. Prihastari, L., Setianingtyas, P., Surachin, A., \& Azkiya, N. M. Effectiveness of $2 \%$ Black Tea (Camellia sinensis) Infusion in Increasing Salivary $\mathrm{pH}$ and Fluoride in Children. J Dent Indones. 2019;26(2): 99-104

15. Waugh DT, Godfrey M, Limeback H, Potter W. Black Tea Source, Production, and Consumption: Assessment of Health Risks of Fluoride Intake in New Zealand. J Environ Public Health. 2017;2017:5120504. doi:10.1155/2017/5120504

16. Gonçalves, N.C.L.A.V. \& Cury, Altair \& Simões, G.S. \& Hara, Anderson \& Rosalen, Pedro \& Cury, Jaime. (2006). Effect of xylitol: Sorbitol on fluoride enamel demineralization reduction in situ. Journal of dentistry. 34. 662-7. 10.1016/j.jdent.2005.12.008.

17. Gupta, P., \& Sandesh, N. (2012). Estimation of fluoride concentration in tea infusions, prepared from different forms of tea, commercially available in Mathura city. Journal of International Society of Preventive \& Community Dentistry, 2(2), 64-68. https://doi.org/10.4103/2231-0762.109371

18. Cao J, Liu J, Zhao Y, Qu H, et al. Fluoride in newer tea commodities. Fluoride 2004;37(4):310-4.

19. Karadas, Muhammet \& Seven, Nilgun. (2014). The effect of different drinks on tooth color after home bleaching. European journal of dentistry. 8. 249-53. 10.4103/1305-7456.130622.

20. Hattab FN, Qudeimat MA, al-Rimawi HS. Dental discoloration: an overview. J Esthet Dent 1999; 11: 291-310

21. Goenka, P., Sarawgi, A., Karun, V., Nigam, A. G., Dutta, S., \& Marwah, N. (2013). Camellia 
sinensis (Tea): Implications and role in preventing dental decay. Pharmacognosy reviews, $7(14)$, 152-156. https://doi.org/10.4103/0973-7847.120515

22. Suyama E, Tamura T, Ozawa T, Suzuki A, lijima Y, Saito T. (2011) Remineralization and acid resistance of enamel lesions after chewing gun containing fluoride extracted from green tea. Australian Dental Journal pp.394-400.

23. Toumba KJ, Curzon ME. A clinical trial of a slow-releasing fluoride device in children.
Caries Res. 2005 May-Jun;39(3):195-200. doi: 10.1159/000084798. PMID: 15914981.

24. Rahardjo, A., Sahertian, R. D., Ramadhani, S. A., Maharani, D. A., \& Latief, F. D. E. (2014). The Effect of Milk or its Combination with Tea and $0.2 \% \quad \mathrm{NaF}$ on Dental Enamel Demineralization Analyzed by Micro Computed Tomography. Journal of Dentistry Indonesia, 21(2). https://doi.org/10.14693/jdi.v21i2.223 